\title{
Johann von Wouwern - en nordeuropæisk humanist på godt og ondt
}

Af $H . V$. Gregersen.

Århundredet mellem reformationen og trediveårskrigen blev i Nordeuropa indledningen til den såkaldte »nytid «. Religiøst fandt bruddet med Rom sted, i videnskaben blev middelalderens skolastiske system forladt til fordel for humanismens krav om lærd forskning i det overleverede kildemateriale, og politisk lagdes grunden til de absolutistiske fyrstestater og det deraf udviklede bureaukrati.

Og endelig udvidedes horizonten hos den slægt, der oplevede denne overgangstid, tilmed i en grad, som deres fædre ikke ville have troet det muligt. Opfindelsen af bogtrykkerkunsten f $\varnothing$ rte til en spredning af læsestof, som havde været ganske ukendt $\mathbf{i}$ tidligere tider, og opdagelserne $i$ de overs $\varnothing$ iske lande førte på. samme tid til et helt nyt syn på vor klode. En udvikling, der kendetegnes af navnene Columbus og Copernicus, var sat i gang, en voldsom udvidelse af hele erfaringsområdet begyndt, altsammen for den jævne mand $i$ dagligdagen begivenheder af omvæltende betydning, så meget mere følelige, som opdagelsen af ædelmetallerne $i$ den nye verden hinsides oceanet tillige gav st $\varnothing$ det til den store prisrevolution i slutningen af det 16.' og begyndelsen af det 17 . århundrede.

Med alt dette er også individualiteternes tid indledt på vore himmelstrøg. Enkeltpersoners liv og virke fremtræder nu ganske anderledes lyslevende end tidligere for eftertidens $\phi j e$. Og det er som regel mennesker, som det nok er værd at stifte bekendtskab med, mennesker af kød og blod, på godt og ondt. Det var menne- 
sker, som i følelsen af, at det gamle levegrundlag var forsvundet, ofte stod noget famlende og usikre over for livets kår. Det var søgende sjæle, for hvem et ståsted i tilværelsen var idealet, og havde de endelig fundet det, gik de som regel ind for dette med en fanatisme, som på en beskuer $i$ eftertiden ofte kan virke uhyggelig. Ikke sært, at troskampe kom til at hærge Jandene, f $\phi r s t$ tredive år igennem $i$ slutningen af 1500-tallet i Frankrig, sá årelange kampe for religiøs og politisk frihed i Nederlandene og derefter trediveårskrigen i Tyskland, fra hvilken voldsomme dø̆nninger også slog ind over vort land.

2: Ind i denne verden fødtes Johann von Wouwern den 10. marts $i$ året 1574 (eller muligvis 1575). Allerede hans oprindelse viser, at han har været et ægte barn af dette omvæltningernes århundrede. Thi hans f $\varnothing$ dested var Hamburg, skønt hans slægt var flamsk-brabantisk, nærmere betegnet fra Kempenland (Campine), men hans forældre havde $\mathbf{1} 1568$ måttet forlade deres hjem i Antwerpen som flygtninge for deres lutherske tros skyld, da hertugen af Albas spansk-papistiske blodregimente havde gjort fremtiden usikker for dem.

Muligt er det, at slægten var af gammel nederlandsk adel, således som dens bekendteste s $ø$ n altid senere hævdede, men man kender kun af navn faderen Nicolaus Wouwer eller Wower og bedstefaderen Johannes Wouwer, og de synes ikke at have været særligt fremtrædende mennesker. Selve slægtsnavnet kan det være noget vanskeligt at få fat på, eftersom det $i$ den foreliggende litteratur gengives på forskellig måde. Wouwer er måske nok den mest korrekte form, thi en af den her biograferedes uvenner hævdede engang, at navnet altid mindede ham om en vred hund, der sagde $»$ vov og bagefter snerrede $\gg$ rrr «. Muligt er det knyttet til en lokalitet, idet man i Belgien finder en Jan van den Wouwere, der i 1624 blev optaget i den spanske ridderstand og som medlem af det spanske krigsråd for de sydlige Nederlande, det nuværende Belgien, indtog en betydelig position i sit samfund.

Det er da meget vel tænkeligt, at slægten er blevet splittet på tidens politisk-religiøse spørgsmål, og de var dengang så dybt- 
gående, at ethvert fors $\emptyset$ gå udsoning på forhånd har været dømt til at mislykkes. Antwerpen havde netop i årene forud for familiens flugt til Hamburg været et centrum for den lutherske bevægelse, og det var her, den voldsomme billedstorm fandt sted i året 1566, som skal have fået Filip II til at blegne af raseri og love hævn over det formastelige kætteri. Mon ikke Johann von Wouwern i sit hamburgske flygtningehjem har fảet indpodet sin gode del af tidens fanatisme, med det helt utilsigtede resultat, at han efter at have rystet hjemmets st $\varnothing v$ af sine f $\phi$ dder for al fremtid var blevet immun over for påvirkninger af den art. Livet igennem forblev han indifferent $i$ religi $\varnothing$ se anliggender.

Barndomstiden og skoleårene i Hamburg er iøvrigt ukendte. Faderen omtaler han aldrig $i$ sine breve, så det $t \phi r$ formodes, at han er $d \phi d$ ret tidligt, mens moderen, der var af hamburgsk slægt og hed Sophia von Winten, i hvert fald endnu levede i 1597.

Han bes $\varnothing$ gte sin hjembys gymnasium, hvor professor Werner Rollfinck (Rolevinck) forberedte ham til optagelse på et universitet, var hans »præceptor «, som det hed. Valget af universitet var noget nær ensbetydende med en stillingtagen til tidens åndelige rørelser, og når derfor Johann von Wouwern allerede $\mathbf{i}$ 16-års alderen tog til universitetet $\mathrm{i}$ Marburg $\mathrm{i}$ det reformerte Hessen, kan dette vel tages som tegn på et brud med hans lutherske fædrenehjem. Kun to år senere, i 1592, flyttede han imidlertid til det dengang ganske unge universitet i Leiden, andsfrihedens højborg $i$ religionsstridighedernes Europa. Her var luften endnu friere end $i$ Marburg.

3: I Leiden fandt Johann von Wouwern sig godt til rette, og inden længe havde han forstảet at skaffe sig gode forbindelser i den lærde verden. Kun 20 år gammel henvendte han sig således i et brev, dateret Leiden $159421 / 5$, til det dengang reformerte Heidelbergs berømteste humanist, professor Janus Gruter. Denne havde i 1592 måttet forlade sit professorat i Wittenberg, fordi han havde nægtet at underskrive den luthersk-ortodokse konkordieformel, men sad nu lunt $i$ den kurpfalziske hovedstad, hvis righoldige bibliotek, „Bibliotheca Palatina «, han ledede, indtil krigens ragnarok også blev hans skæbne. Thi kurfyrst Frede- 
rik af Pfalz havde i vinteren 1618 fors $\varnothing$ gt sig som konge af B $\varnothing$ hmen, men slaget på det Hvide Bjerg gjorde ende på hans kongedømme, og da den Katolske Ligas hær i 1622 under ledelse af den fra Christian IVs historie så bekendte general Tilly nåede Heidelberg, blev hele biblioteket gjort til bytte. For Gruter kom det til at betyde, at han for stedse forlod al lærdoms syssel. Resten af sine levedage viede han sit havearbejde.

Til denne mand henvendte Johann von Wouwern sig og forelagde ham med en tyveårings hele appetit på livet sine litterære planer. $O g$ han var ikke bange for at tage munden lovlig fuld. Han agtede at udgive en række antikke forfattere, nævner særligt Severianus, Curius Fortunatianus og Rutillius Lupus. Måske Gruter i sit værdifulde bibliotek kunne være ham behjælpelig med at finde manuskripter af de pågældende forfattere? Det var, hvad den unge mand attråede, og hermed var hans studier straks fra ungdomsårene lagt $i$ faste baner. Hans hu stod til humanismens syssel med de antikke forfattere og til arbejdet med at skaffe gode, trykte, kommenterede udgaver af deres kærker.

Til studier af den art kunne der vanskeligt findes et mere velegnet sted end Leiden, hvor den berømteste filolog fra tiden omkring 1600, franskmanden Joseph Justus Scaliger, havde sit virke. Også hans skæbne var blevet formet af tidens uro. Under et ophold i den tyske rigsstad Strassburg i 1572 havde han hørt om Bartholomæus-nattens rædsler i Paris, da papistiske fanatikere s $\varnothing$ gte at tilintetg $\emptyset r e$ huguenotterne, og han besluttede da for stedse at vende sit fødeland ryggen. Efter en del omflakken især i tyske byer og egne var han i 1590 blevet professor i Leiden, og herfra opretholdt han forbindelse med adskillige af det daværende Europas førende ånder, blandt dem Hugo Grotius, Daniel Heinsius og Janus Gruter.

Hvor nære Johann von Wouwerns forbindelser var til sden store Scaliger *, som han gerne kaldtes, kan det være noget vanskeligt at få fat på, idet man kun har Wouwerns noget flotte bemærkninger herom til ungdomsvennen Sebastian von Bergen at holde sig til, og de præges tydeligvis af studentikos bedreviden og fripostighed over for den aldre universitetslærer. »Scaliger forelæser ikke offentligt«, hedder det således $i$ et brev 
fra 1594, »og agter heller ikke at sætte sin vaerdighed over styr. Han er en mand på godt 50 år, ugift, at middelst $\emptyset r r e l s e$, fransk af udseende og helliger sig helt matematikken (han arbejdede dengang på et kronologisk værk). Om kort tid vil han publicere noget, som ligger lige så langt over den menneskelige forstand, som de gamle filosoffer ligger langt tilbage i fortiden. Han overtræffer sin forgænger Lipsius i sprog og kritik, men måler sig ikke med denne i undervisningsfardighed «.

Scaliger anså det for et af sine livsmål ud fra sit opholdssted i Holland at virke for de højere filologiske studiers trivsel i det tyske kulturområde, som han gennem de mange års flygtningetilværelse var kommet til at føle sig knyttet til. I årene op imod 1600-tallet samlede han derfor en kreds af nordtyske, særligt hamburgske studerende om sig, og gennem dem søgte han at fremme studiet af de antikke, specielt senantikke forfattere. Resultatet heraf blev en række værker, der ikke just udmærker sig ved dybtgående forskninger, men mere gik $i$ retning af det kompilatoriske, af at sammenstille, hvad der forelå fra forskellige forfatteres hånd om det pågældende emne. Den litterære analyse af deres værker og disses betydning for samtiden trådte derimod mere i baggrunden.

Johann von Wouwern anses $\mathrm{i}$ almindelighed for at have været den ledende og den, der nåede videst blandt disse filologer, men

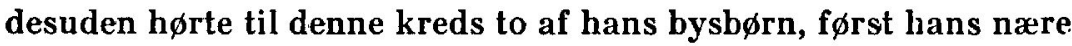
ven Henrich Lindenbrog og senere den noget yngre Geverhart Elmenhorst. Wouwern har da heller aldrig s $\emptyset \mathrm{gt}$ at lægge skjul på sit discipelforhold til den store Scaliger, og fra sin lange udenlandsrejse har han atter og atter sendt sin læremester breve, der alle vidner om stor højagtelse for den lærde filolog.

4: Udenlandsrejser var i de tider gerne et fast led $i$ en ordentlig videnskabelig uddannelse, og også Johann von Wouwern fik i sin ungdom set meget af sin samtids Europa. Allerede i 1593 synes han således at have været $i$ England, men opholdet her blev dog kun af kort varighed, da der i London udbrød en pest, som krævede 2000 dødsofre om ugen.

I 1595 og 1596 var Johann von Wouwern hushovmester for en 
ung adelsmand, en hr. von Scagen und Bergernhorn, men derefter tog han ud på sin store udenlandsrejse, der skulle komme til at strække sig over flere år. Først gik rejsen til Frankrig, til Paris, hvor han tilbragte en tid sammen med ungdomsvennen Henrich Lindenbrog, med hrem han allerede i Leiden havde dyrket de antikke forfattere. I Paris's righoldige biblioteker fremb $\phi d$ der sig ypperlig lejlighed til at finde sjældne, hidtil upåagtede eller kun lidet benyttede manuskripter, og de to unge humanister var ikke sene til at gøre brug af den. Deres iver efter at opsnuse gamle pergamenter er da heller ikke forblevet upåagtet, thi under studier i det berømte Saint Victor klosters bogsamling blev de af en munk beskyldt for at have tilegnet sig 16 uerstattelige håndskrifter. Om Henrich Lindenbrog ved vi, at han af den grund en tid sad fængslet, og det samme har nok også været tilfældet med Johann von Wouwern. I hvert fald klæbede siden hen $\emptyset$ genavnet »les corsaires de Hambourg « til deres navne, men de har altid nægtet sig skyldige, og den omstændighed, at de slap ud ved den kendte franske humanist Pierre Dupuys mellemkomst, kan vel også tages som bevis for, at de har været sagesløse.

For Henrich Lindenbrog havde det ubehagelige intermezzo til følge, at han vendte hjem til Hamburg, men venskabet mellem de to unge fifologer varede ved. De folte sig som br $\phi d r e$, kaldte sig $\mathrm{i}$ hvert fald således $\mathrm{i}$ breve til hinanden, og Lindenbrogs fremtid lå stedse Wouwern på sinde. Engang foreslog han ham at s $\varnothing$ ge et historisk eller juridisk professorat i Groningen i West Friesland, senere, da han selv var kommet til ære og værdighed hos hertug Johann Adolf, skaffede han ham stillingen som bibliotekar ved det gottorpske bibliotek, og her blev Lindenbrog til sin død i 1642.

Men tilbage til Paris. Johann von Wouwern lod sig ikke standse af denne ubehagelige oplevelse, men fortsatte ad lærdomsvejen. If $\phi$ lge Geverhart Elmenhorst, der har beskrevet hans levnedsl $\phi b$, skal han have gjort en række fornemme bekendtskaber $i$ den franske hovedstad. Han skal foruden den førnævinte Pierre Dupuy have lært dennes broder Francois Dupuy at kende. Denne mand ejede et bibliotek, som if $\varnothing$ lge Wouwerns begejstrede ud- 
sagn til Gruter kunne tage det op med oldtidens ber $\varnothing$ mte bibliotek i Alexandria. Desuden skal han have plejet omgang med humanisten Jacques Bongars, der en tid var minister hos Henri IV, men det turde dog være et spørgsmål, om man helt kan stole på Elmenhorsts noget farvede beretning. Det er vel næppe troligt, at en ung studerende har formået at skaffe sig så indflydelsesrige bekendtskaber.

Derimod står det fast, at han er truffet sammen med den lærde Isaac de Casaubon. I 1598 meddelte han vennen Henrich Lindenbrog følgende om opholdet her: $\gg$ Jeg opholder mig nu hos. Casaubonus. Om ham skal du vide, at han er den lærdeste mand i vor tid og langt overtræffer dem, som vi hidtil har sat højest. Han er dertil overordentlig elskværdig, og når han er i gang med studier, vil han ikke forstyrres «. Samværet med Castubon har åbenbart været »berigende« for Wouwern, thi han har senere måttet høre for, at han gjorde lidt for grundigt brug af Casaubons litterære arbejder. Det varede ikke længe, før franskmanden Maussac direkte beskyldte Wouwern for at have plagieret den lærde filolog, men den slags var ikke ualmindeligt $i$ de tider. Forfatterrettigheder var endnu et ganske ukendt begreb.

Casaubon var professor i calvinismens metropol Genève, og det betyder i denne forbindelse, at Johann von Wouwern fra Frankrig var på vej til Italien, renæssancens hovedland, der lige siden har været et eftertragtet mål for alle litterært, historisk og kunstnerisk interesserede. Her var antikkens ånd endnu levende, her var hjemstedet for de forfattere, der udgjorde en stor del af hans tilværelse, og her var det stadig muligt at gøre sjældne fund fra fortiden.

5: I Italien arbejdede Wouwern derfor mere intenst end nogensinde tidligere og det $\mathrm{i}$ hele to år. Han kom $\mathrm{i}$ forbindelse med adskillige af romerkirkens høje prælater og kardinaler og skal endda have fået foretræde hos selveste paven, Clemens VIII, der var stærkt interesseret i studiet af sit lands fortid. Når onde tunger senere hævdede, at Johann von Wouwern i Rom var blevet konvertit for derved at skaffe sig mere uhindret adgang til Italiens righoldige biblioteker og kunstsamlinger, kan en så- 
dan påstand vist uden videre afvises. Der er intet $\mathbf{i}$ det foreliggende kildemateriale, der kan begrunde en sådan opfattelse. Han har tværtimod selv afvist dette rygte på det bestemteste, og efter opholdet $i$ Italien har han $i$ hvert fald ikke længere haft forbindelse med katolikker.

I et brev fra 1603 har han engang fremhævet, at rygtet i sin tid var blevet sat $i$ oml $\varnothing b$ af nederlændere og tyskere $i$ Rom, som havde fattet mistanke til ham på grund af hans fortrolige omgang med kardinaler og pavelige ministre. Han ville derfor gerne advare alle Roma-farere imod deres egne landsmænd. Selv nogle af hans venner havde været nysgerrigt ondsindede og havde interesseret sig for ham på en uvenlig måde.

Hvad hans egen tro angik, fremkom han ved samme lejlighed med nogle udtalelser, der klart viser forbindelsen mellem humanismens og renæssancens dyrkelse af mennesket og den senere oplysningstids tro på en »naturlig\& religion, der ikke byggede på kirkens åbenbaringstro, men på den menneskelige fornuft. $\gg$ Det er en menneskelig rettighed og en naturlig rimelighed, at enhver må ære og agte, hvad han mener at finde for godt. Den enes religion bringer den anden lige så lidt skade som fordel. Det lader sig desuden ikke nægte, at de mennesker, der har taget sig for at reformere religionen, ofte $i$ uforsigtig iver har klippet meget stof i stykker, som de måske kun havde behøvet at sprætte op«. Hans syn på det religiøse var derfor bestemt som han skriver - af s sensus communis (common sense), sund sans. Han havde nu den tro, at enhver syntes bedst om sin egen kæreste og anså hende for den smukkeste!

Johann von Wouwern var med andre ord rationalist. Hans tro byggede på hans fornuft, men det er jo ikke kristentro, hvis den $i$ det hele taget kan kaldes en tro! Ud fra denne forudsætning er det også adskilligt lettere at være tolerant $i$ religiøse spørgsmål. Der står jo ikke noget på spil; der er ingen evig sandhed at forsvare. I så henseende er ligheden mellem det 16. århundredes humanisme og det 18. århundredes oplysningstid iøjnefaldende, og det er betegnende, at vor moderne verden står i gæld til begge disse åndsstrømninger.

Det må altså anses for sikkert, at Johann von Wouwern ikke 
er trådt over til romerkirken, selv om hans ophold i Italien blev langvarigt. Hele to år var han der, fra 1600 til 1602. Han drev indgående biblioteksstudier i de bogsamlinger, der var tilgængelige for ham, og han eftersporede med stor interesse, hvad han kunne finde af inskriptioner på oldtidens monumenter. Hans gode bekendt i Heidelberg, Janus Gruter, var i de samme år beskæftiget med en udgave af de gamle monumenters indskrifter, og Wouwern kunne da give ham mangt et vink. I ărene 160203 udkom Gruters værk under titlen Inscriptiones antiquae totius orbis Romani\& under medvirkning af Scaliger i Leiden og Marcus Welser, en dengang kendt humanist i Augsburg, men også Wouwern bør der tillægges en beskeden andel i disse binds fremkomst. I Siena fandt han således frem til en inand af samme interesse, Celso Cittadino, og om ham kunne han melde Gruter, at han ikke kendte nogen, som med større flid og omhu havde indsamlet gamle inskriptioner $i$ Italien.

I den forbindelse gjorde Wouwern et fund, som han selv og flere med ham tillagde den st $\varnothing$ rste betydning, idet det i 1601 i Rom lykkedes ham at få en kunstner til at aftegne monumentet over Marcus Aurelius Antonius' kampe med markomannerne, den såkaldte Columna Antoniana. Denne tegning vakte begejstring hos adskillige tyske humanister, for hvem et dybere indblik $\mathbf{i}$ oldtidens historie var en hjertesag. Typisk er $\mathbf{i}$ så henseende Gruters udbrud ved synet af ridset. Selv om han netop i den samme uge agtede at indtræde $i$ ægtestanden, hævdede han, at han hellere ville kysse denne tegning end sin unge forlovede!

6: Renæssancens Italien havde også været Niccolo Machiavellis fædreland, og det har sikkert ikke været uden betydning for Wouwern, at han havde rig lejlighed til at følge de jævnligt skiftende politiske forhold i de forskellige italienske fyrstestater. Utænkeligt er det ikke, at det er i Italien, han har fattet planen om at skaffe sig en fremtidig karriere som statsmand hos en ligesindet fyrste. I 1601 hævdede han $i$ et brev til ungdomsvennen Sebastian von Bergen i Hamburg, at han havde fåt tilbudt et af de største og »mest gehejme statsembeder hos storhertugen af Firenze, et embede, som var eftertragtet af mange 
af de fornemste herrer. Han havde dog ment at måtle sige nej til tilbudet, fordi han havde indset, at han samtidig med en sådan cæsarisk oph $\varnothing j$ jelse ville komme til at leve i en stadig angst for mindst 1000 Brutus'er«. Under foregivende af svaghed havde han skyndsomst forladt Firenze.

Hvor meget der har været om snakken, er ikke mere til at sige, thi nagtes kan det ikke, at Johann von Wouwern besad en evindelig trang til at fremhæve egne fortjenester i sine breve. Livet igennem var han en uhyre selvoptaget mand, der med en sjælden frimodig arrogance søgte at sætte sig i relief i forhold til sine medmennesker. Hans brændende ærgerrighed fik ham imidlertid snart til at indse, at det ville blive en lang og trang vej at vinde ære og ber $\varnothing$ mmelse gennem videnskabeligt arbejde. Magtens tinde ville kunne nås langt lettere $i$ det politiske liv. Som statsmand hos en oplyst fyrste ville han rigtig fả lejlighed til at virke $\mathrm{i}$ humanismens ånd. Med denne erfaring, indhøstet under studieårenes vandringer fra land til land, har han da i 1602 kunnet ryste Italiens st $\varnothing v$ af sine f $\varnothing d d e r$. Det er sket i forvisningen om, at han burde søge sin fremtid nord for Alperne.

7: I Tyskland skal Johann von Wouwern i 1603 have fået tilbudt stillingen som kejserlig råd ved kejser Rudolf II's humanistiske hof i Prag, hvor Tycho Brahe i sine sidste leveår havde fundet et fristed. Det blev nu ikke til noget, hvad enten det så skyldtes Wouwerns modvilje mod rekatoliceringens $\phi$ gede styrke efter århundredskiftet, eller, at denne sag kun har varet et udslag af hans lobske fantasi.

Hjemkommen til Hamburg synes han imidlertid ikke at have befundet sig vel, og hans håb om en fremtidsstilling ved et fyrstehof fik ham da i 1603 til at henvende sig til Nordeuropas mest fremtrædende regent, Christian IV, konge af Danmark og Norge, hertug af Slesvig og Holsten. Vejen til at påkalde sig kongens opmærksomhed var den i datiden ikke ualmindelige at skrive en lovtale, der $i$ et svulstigt og umådeholdent sprog priste Christian IV for kendte og ukendte dyder, forfattet på renæssancens formfuldendte latin. Men Christian IV og hans omgivelser følte sig ikke umiddelbart tiltalt af at modtage hyldest 
af en mand, der uddannet på calvinske universiteter måtte stå i et noget speget forhold til det lutherske. Skellet mellem de to konfessioner var på den tid skarpere end nogensinde, og $i$ Christian IV's lutherske rige var der derfor ingen plads for en mand af Johann von Wouwerns åndelige habitus.

Hans »Panegyricus« til den danske konge blev dertil meget unådigt optaget i Hamburg, hvor Christian IV ikke for intet blev anset for en farlig nabo. Johann von Wouwern havde dog blot spot til overs for sine angribere $\mathrm{i}$ den anledning. $\gg$ Disse superkloge duksedrenge, disse uforstandige sækkepibeblæsere, som tror, at man er nødt til at tilbede deres skygger «, lød hans svar, men med disse udgydelser havde han også fraskrevet sig enhver mulighed for at blive ansat $i$ sin f $\varnothing$ debys administration.

Han synes dog ikke at have taget sig denne udvikling særlig nær, men kastede sig i stedet over sine filologiske studier. Hans vigtigste værker blev udarbejdet $\mathrm{i}$ årene mellem 1603 og 1607, og de grundlagde hans ry som forsker, men rigtignok samtidig også hans dårlige omd $\varnothing$ mme. St $\not$ rst opsigt vakte hans $\gg$ De Polymathia Tractatio «, som kendere påstod var taget lige ud af Casaubons værker. End ikke den store Scaliger lagde fingeren imellem, idet han udtalte, at selve bogen var god, blot var det en anden, der var dens ophavsmand. *Wouwern var ikke mand for at bringe slige varer til torvs. Han havde smykket sig med fremmede fjer *.

At det pågældende litterære tyveri ikke var det eneste, han havde på samvittigheden, påvistes kort efter hans død af vennen Henrich Lindenbrog, som havde fundet ud af, at Wouverns lille traktat Dies æestiva sive de unbra pægnion* fra 1610 i betankclig grad mindede om et af latindigteren Janus Schedes værker.

Var hans fors $\phi g$ på forfatterbanen således noget uheldige, hævdede han sig ganske anderledes smukt som udgiver og kommentator af en række latinske oldtidsforfattere. Det var især skribenter fra senantikken, der havde hans hjerte, således Minucius Felix, Firmicus Maternus, Apulejus, Sidonius Apollinarius og Fulgentius, men også den noget ældre Petronius fik han udsendt en udgave af. 
8: Håbet om en politisk karriere blev dog ikke forladt til fordel for det litterære arbejde. Johann von Wouwern deltog således på holstensk side $i$ en del forhandlinger om grænsespørgsmål, der i de pågældende år f $\not$ rtes mellem Hamburg og Holsten. Ligeledes skal han have haft foretræde ved hoffet i Braunschweig og endda af Rantzauerne være blevet sendt til forhandlinger i de sydlige Nederlande.

Snart derefter fik han ansættelse hos grev Enno $I I I$ af Ost Friesland, men da forholdene ved dette liliputhof var ham for snævre, undlod han ikke at se sig om efter noget bedre. 11607 stod heldet ham bi, da han for resten af sine dage knyttedes til det humanistiske hof på Gottorp hos den frisiske grevindes tvillingbroder, hertug Johann Adolf.

Forinden havde han dog som hofråd for grev Enno deltaget i de indledende fredsforhandlinger mellem Spanien og Nederlandene. For Ost Friesland var disse af den største betydning, fordi havnestaden Emdens fremtidige ve og vel var afhængig af et gunstigt udfald. Hollænderne havde efter bedste evne s $\phi \mathrm{gt}$ at holde Emden ude fra forhandlingerne, som trak så meget $i$ langdrag, at Johann von Wouwern efter sin ansattelse pá Gottorp måtte have hertug Johann Adolfs tilladelse til at deltage som befuldmægitiget gesandt for grev Enno. I 1608 var han af den grund i Haag, og det ville naturligvis kun ligne ham dårligt, om han ikke $i$ sine breve til nær og fjern udbasunerede betydningen af, at han var med til den endelige udformning af traktaten, der gav de tidligere kæmpende parter 12 års fredstilstand. Med »Ulyssæisk list « - listig som en Odysseus - havde han opnået, at også Einden kom ind under traktatens bestemmelscr. At han ved samme lejlighed havde været med til at skrive en scarmen* til ære for den spanske marquis Ambrosio Spinola, den af efterverdenen navnlig fra maleren Velasquez' kunst så bekendte feltherre, skabte ham imidlertid siden hen en række fjender $i$ de nordlige Nederlande.

Hjemvendt fra disse betydningsfulde begivenheder lykkedes det Johann von Wouwern i løbet af forbavsende kort tid at gøre sig til hertug Johann Adolfs altformående minister. Medvirkende hertil har været en vis følelse af kongenialitet mellem de to, 
sikkert ikke mindst en f $\phi$ lge af fælles opfattelse af, hvorledes en moderne stat skulle ledes. Johann Adolf havde ikke for intet fåt sin opdragelse ved det calvinske hof i Hessen, et af centrerne for datidens tyske humanisme. Allerede $i$ flere år havde gottorperhertugen $s \phi$ gt at reformere sit land efter hessisk forbillede, men hans fors $\emptyset \mathrm{g}$ på at udvide fyrstemagten var blevet uvilligt modtaget hos stænderne, og bedre blev det ikke, da han for alvor prøvede på at reformere landets kirkelige anliggsender. Herved stødte han på en mur af modstand hos sine undersâtter og det ikke mindst blandt de jæunere lag.

Hertugen måtte derfor søge til fremmed hjælp for at få gennemf $\varnothing \mathrm{rt}$ sine idealer, og blandt disse indkaldte hessere, bremere og nederlændere lykkedes det meget snart Johann von Wouwern at blive en af de mest fremtrædende. Hertil bidrog måske ikke mindst, at han $i$ hertugen havde en fyrste med betydelig interesse for kulturelle anliggender. Det hertugelige bibliotek på Gottorp udbyggedes således til at blive en af tidens anseligste videnskabelige bogsamlinger, der blandt andet indeholdt en rig skat af middelalderlige håndskrifter, og $i$ årene, der fulgte, $\phi$ gedes det ved betydelige testamentariske gaver, sảledes fra Johann von Wouwern.

En ulempe for hertugens styre var imidlertid den konstante finansn $\varnothing$, der til dels skyldtes en for overdådig hofholdning. Også på dette område søgte Johann von Wouwern at råde bod, omend kun med ringe held, og det var derfor ikke sá sært, at eftertiden har dømt ham hårdt herfor og naturligvis tilskrevet ham de værste hensigter. "Ein Beschützer der Sekten, ein Anfänger des holländischen Diekwesens, ein Fortsetter und Vorrichter der grossen Schattung «, hedder det $\mathrm{i}$ denne forbindelse om ham. Digevæsen og nyordning af landets skatteindtægter, det lyder $i$ og for sig altsammen meget godt og er $i$ god overensstemmelse med, hvad en moderne stat måtte $\emptyset$ nske, men det betød samtidig hårdere arbejdshyrde og $\varnothing$ gede skatter for det jævne folk, og den slags var selvf $\varnothing$ lgelig ikke egnet til at g $\phi r e$ en mand popular.

9: Størst opsigt vakte imidlertid Johann von Wouwerns ind- 
greb i Slesvig-Holsten-Gottorps kirkelige anliggender. Han fik således gennemført, at de kirkelige afgifter skulle inddrives af verdslige myndigheder, og at et såkaldt »kirkeråd « skulle kontrollere kirkernes regnskaber. Da disse foranstaltninger tillige sigtede mod en ændring $i$ kirkens bekendelsesgrundlag $i$ calvinsk retning, rejste de en efter tidens forhold voldsom modstand, der i slutningen af 1609 f $\phi r t e$ til, at den lutherske generalprovst Jacob Fabricius måtte trække sig tilbage og forlade landet. Embedet besattes derefter af en ganske uværdig person, Philip Caesar fra Hessen.

Regeringen havde i 1609 søgt at bremse kirkekampen ved at udstede et edikt, der under trusel om embedsfortabclse og fyrstelig unåde og straf forbød den gottorpske landskirkes præster senhver utidig og utilbørlig smæden, skælden og ford $\phi$ mmen såvel som navns nævnelse fra præedikestolene«. For en tilfældig betragtning kunne et sådant forbud synes både rimeligt $\mathrm{og} \mathrm{i}$ god overensstemmelse med de bedste humanistiske traditioner, men det bør ikke glemmes, at uroen i kirken var blevet fremkaldt af regeringens calviniserende tendenser og af den verdslige administrations indgriben $i$ anliggender, der hidtil havde været anset for rent kirkelige.

At Johann von Wouwern har varet en af bagmandene for denne politik, fremgår alene af den omstændighed, at han selv blev »kirkepræsident « for konsistoriet og som sådan, assisteret af to jurister, tog stilling $i$ alle kirkeretlige spørgsmål. På baggrund af de tidligere citerede udtalelser om hans opfattelse af religiøse spørgsmål må det virke forstemmende, at han har ment sig kvalificeret til at optræde som dommer i religionssager, og der er intet, der tyder på, at han $i$ tidens løb havde skiftet standpunkt.

Allerede af sine samtidige blev Johann von Wouwern regnet for den egentlige ophavsmand for den gottorpske regerings nye kurs efter 1608, og der er næppe grund til at betvivle rigtigheden af denne opfattelse. Som leder af regeringens daglige førelse i disse år viste han sig tydeligt påvirket af Machiavellis tanker om renæssancens stærke stat, som det enkelte individ havde at indordne sig under, hvis det ikke ville udsætte sig for 
tilintetgørelse. Måske har Johann von Wouwerns granseløse forfængelighed og evindelige trang til selvhævdelse $\mathrm{i}$ forbindelse med et kolerisk temperament været med til at fremme en udvikling, der gik $i$ retning af at behandle anderledes tænkende med skånselslǿs kynisme.

Hans indflydelse på hertugen var så stor, at end ikke hertuginde Augusla, en søster til Christian IV, evnede at få hidf $\varnothing \mathbf{r t}$ en xendring. Hun måtte finde sig i, at generalprovst Jacob Fabricius også blev afsat som hofpræst, og vandrede derfor, uanset vejret, søndag efter søndag i stille protest til fods den lange vej fra slottet til domkirken, hvor domkapitlet endnu formåede at holde stand over for den calviniserende kirkepolitik.

I den dansktalende egn af Slesvig-Holsten-Gottorp blev præsten i Hellevad-Egvad, Niels Heldvad, der allerede i 1597 havde skrevet imod den truende calvinisering, fordrevet fra sit embede ved så utiltalende metoder, at han med føje kunne kalde Johann von Wouwern en »legemliggjort djævel«. Mordet på Aabenraas borgmester Claus Esmarch i 1610 blev måske endda af Johann von Wouwern benyttet til at ramme et par af landets gamle, ansete slægter, idet den pågældendes svigerforældre Wolf Kalundt og Margrethe von Eitzen på foranledning af hertugens hofråd blev underkastet tortur og kendt skyldige. \Jeg gruer og gider ikke tænke på det«, skrev han samtidig til sin fortrolige, Sebastian von Bergen, der nu var blevet borgmester i Hamburg. En broder til den sidstnæunte af de dødsdømte, dr. jur. Paul von Eitzen, lykkedes det nogle måneder senere Johann von Wouwern at få offentligt skandaliseret. Som ophavsmand til denne affære opgives udtrykkeligt hofrådens mest trofaste tjener, Berend Nobis, et ualmindeligt slet menneske, der på sin senere livsbane en tid optrådte som hekseinkvisitor og til sidst $i$ et anfald af sindssyge begik selvmord ved at styrte sig ind $\mathrm{i}$ et bål.

10: Johann von Wouwerns magt og indflydelse var trods alle overgreb i stadig stigen, og også i $\emptyset$ konomisk henseende bedredes hans stilling, idet han $\mathrm{i}$ henholdsvis 1609 og 1610 overtog forvaltningen af Aabenraa og Gottorp amter — for ovrigt til stor fortrydelse for den hjemlige adel, der på landdagen i 1610 
krævede, at amtmandsembederne skulle forbeholdes landets egne børn. Hånd $\mathrm{i}$ hånd med de mange indtægter fra sine forskellige embeder var han efterhånden blevet ejer af betydelige jordegodser i Eiderstedt, men trods al timelig fremgang lakkede det mod enden med hans magt: et stadigt skrøbeligere helbred undergravede hele hans sociale position.

Allerede i 1609 havde Johann von Wouwern i sine breve klaget over hovedsmerter, og i løbet af 1611 forvarredes hans tilstand. Han led da efter eget sigende af en uhelbredelig svulst på blæren, desuden af podagra og forstoppelse i milten, af smerter i underlivet, hjertebanken, hoste og sveden. I sit sidste leveår havde han ikke en eneste dag uden smerter, sả hans tilværelse formede sig som en række uendeligt trøstesløse dage. Da d $\phi$ den indtraf den 30. marts 1612, var det derfor en mærkelig livsbane, der blev afsluttet; et menneske, der i hastigt løb havde nået sit livs middagshøjde og opfyldelsen af de dristigste drømme, måtte med ét give afkald på alt, hvad det med brændende begær havde tragtet efter og også opnået.

Testamentet er det sidste, der er bevaret fra hans hảnd, og det er ikke helt almindeligt i sin form. Nøje bestemmes således gravskrift, og hvem, der skulle prædike over ham, helst Philip Caesar, men under ingen omstændigheder Georg Rose inde fra domkirkan! Ordene fra Jobs bog: $\nabla J e g$ ved, at min genløser lever « skulle være teksten for begravelsestalen, som der samtidig afsattes 20 rdl. til. Måske har han da i smertensårene fundet trøst ved at beskxftige sig med Job og hans gudhengivenhed trods alle lidelser?

Bogsamlingen skulle indlemmes i hertugens bibliotek. Berend Nobis skulle udarbejde et inventarium. En lærd, hclst Danie? Heinsius i Leiden, skulle sorge for trykning af hans efterladte skrifter, og lærde, der på prent ville fremdrage hans livs bedrifter, skulle have $60 \mathrm{rdl}$. Det vides, at de blev ndbetalt til Geverhard Elmenhorst, Adam Olearius og Nic. Johs. Crusius. Andre penge skulle gå til vajsenhuset i Hamburg, til fru Anna Kcllinghusen og frk. Elisabeth Kellinghusen (hhv. 400 og 500 rdl., samt hans møbler). Erindringsbægre skulle gives til tre af hans kolleger ved hoffet, Hieronimus Müller, Ab̉el Spiess og 
Dietrich Vicke. Tjenerne Berend Nobis, Thomas Esmarch og Hildebrandt fik hver en sum udbetalt (hhv. 100, 50 og 50 rdl.). Med rystende hånd har han undertegnet dette dokument, der endnu findes bevaret, med navnet Iohan van Wouver.

Henvisninger: Ud over den i Dansk Biografisk Leksikon vedr. Wower (ved Johanne Skovgaard) og i H. V. Gregersen: Niels Heldvad anførte litteratur:

Biographie Nationale de Belgique (1936-38) vedr. Wouwere;

Allgemeine Deutsche Biographie vedr. Elmenhorst, Gruter, Lindenbrog, Scaliger, Wowern;

J. Smith: Slesvigske Amtsforvaltere vedr. Nobis;

Wilckens: Leben der Berühmten Lindenbrogiorum (Hamburg 1723).

M. h. t. det gottorpske bibliotek kan tilføjes Harry Schmidt: Das älteste Verzeichnis der Gottorfer Bibliothek aus dem Jahre 1590 (Nordelbingen bd. 25, 1957, s. 19 ff.). Heri afvises, at biblioteket som almindeligt antaget - skulle være grundlagt 1606 .

I det eksemplar af Niels Heldvads *Sylva Chronologica «, der findes i British Museum i London, er der indfort nogle håndskrevne notater, der bør tillægges en vis betydning, da det pågældende eksemplars f $\varnothing$ rste ejermand var forfatterens s $\emptyset$ n Laurids Heldvad, der døde 1677 som præst og provst i Svendborg.

Til s. 279, året 1608, står tilføjet: ,Johan von Wowern fanget ein newes Kirchen Regiment im Hertzogthumb Sleswig Holstein an, der Kirchen Ordinantz zuwidern. Heluaderus wirdt remouirets.

Til s. 281, året 1612: ,Johan von Wouwern stirbt zu Sleswig den 30. Martij, vnd wird im Thumb begraben. Hic situs est Nero, laicus merus vipera clero. Qui Juris, Ruris, Ducis Damnabile Virus «. (Her ligger Nero, sk $\phi$ nt blot lægmand en slange for gejstligheden; han, som var en ford $\phi \mathrm{mt}$ gift for retfærden, landfolket og hertugen).

Til s. 282, året 1610: >Nicolay Heldwaderus bekombt hieraufff sein Phar wiederumb. Dominica Trinitatise.

Til s. 287, året 1612: sJohan von Wouwern remouiret vnd vorjaget Pastoren, im Hertzogthumb.. 